\title{
MARRIAGE AND FAMILY PATTERNS WITH LONG-TERM SPINAL CORD INJURY
}

\author{
By Frank S. Deyoe, M.D.Ed. \\ Med. Rehabilitation Co-ordinator, Veterans Administration Hospital, \\ West Roxbury, Massachussetts 02132, U.S.A.
}

DURING the last annual meeting of the International Medical Society of Paraplegia held in the United States I reported briefly on the current status of patients with spinal cord injuries of long duration. Described at that time were achievements in the areas of physical-functional skills, education, vocations and avocationalsocietal activities. Time limitations prevented discussion of the marriage and family patterns of this group and it is this area that I now wish to describe.

TABLE I

Disability Classification

\begin{tabular}{|c|c|c|c|}
\hline Level & No. & $\mathrm{SC}^{\star}$ & NSC + \\
\hline $\begin{array}{l}\text { Tetraplegic } \\
\text { C5 and above } \\
\text { C6 and below }\end{array}$ & $\begin{array}{l}40 \\
27\end{array}$ & $\begin{array}{l}18 \\
16\end{array}$ & $\begin{array}{l}22 \\
\text { II }\end{array}$ \\
\hline Subtotal & 67 & 34 & 33 \\
\hline $\begin{array}{l}\text { Paraplegic } \\
\text { High Para (TI-T6) } \\
\text { Mid Para (T7-TI2) } \\
\text { Low Para (LI-L5, Sacral) }\end{array}$ & $\begin{array}{l}54 \\
74 \\
24\end{array}$ & $\begin{array}{l}32 \\
38 \\
16\end{array}$ & $\begin{array}{r}22 \\
36 \\
8\end{array}$ \\
\hline Subtotal & 152 & 86 & 66 \\
\hline TotAL & 219 & & \\
\hline
\end{tabular}

$\star \mathrm{SC}=$ Service connected.

$\dagger$ NSC $=$ Not Service connected.

The study group was composed of 219 veterans who returned to a spinal cord injury centre during a two-year period for medical review or treatment (Table I). All had previously been treated in comprehensive rehabilitation programmes in Veterans Administration Hospitals and had been living outside of the hospital from periods of 2 to 30 years. Of this group, 67 had cervical cord lesions; the remainder had lesions of the dorso-lumbar or sacral areas of the cord.

A patient profile summarises the basic characteristics of the study group (Table II). Ages of the subjects ranged from 21 to 75 years; the number of years paralysed ranged from three to over thirty with the largest number in the time intervals shown. (Incidently both of these intervals have increased from two to 
four years since the data was recorded and this information will be up-dated as soon as the status of all individuals has been verified.) Cause of injury and years outside the hospital also are modal. This discussion will focus on the marital

TABLE II

Patient profile

\begin{tabular}{|l|l|l|}
\hline & Paraplegic & \multicolumn{1}{|c|}{ Quadriplegic } \\
\hline Median age & 45 & 40 \\
Median age when injured & 26 & 22 \\
Years paralysed & $20-24$ & IO-I4 \\
Injury & Combat & Motor vehicle \\
Hospitalised & Less than 2 years & Less than 3 years \\
Living out of hospital & 20-24 years & IO-I4 years \\
Marital status & Married & Married \\
Environment & Suburbs & Suburbs \\
Home & Ranch & Ranch \\
Employment & Not current & Not current \\
Cultural, societal, & Unlimited & Unlimited \\
avocational & & \\
& & \\
\hline
\end{tabular}

TABLE III

Marriage patterns

\begin{tabular}{|c|c|c|}
\hline & Total & Currently married \\
\hline \multicolumn{3}{|c|}{ Paraplegia } \\
\hline $\begin{array}{l}\text { SC } \\
\text { NSC }\end{array}$ & $\begin{array}{l}86 \\
66\end{array}$ & $\begin{array}{l}6 \mathrm{I}(7 \mathrm{I} \%) \\
48(73 \%)\end{array}$ \\
\hline Subtotal & I52 & $109(72 \%)$ \\
\hline \multicolumn{3}{|c|}{ QUADRIPLEGIA } \\
\hline $\begin{array}{l}\text { SC } \\
\text { NSC }\end{array}$ & $\begin{array}{l}34 \\
33\end{array}$ & $\begin{array}{l}17(50 \%) \\
20(61 \%)\end{array}$ \\
\hline Subtotal & 67 & $37(55 \%)$ \\
\hline TOTAL & 219 & I $46(67 \%)$ \\
\hline
\end{tabular}

status, environment and home situation of men with long-term spinal cord injury.

At the time of interview, 72 per cent. of the paraplegics and 55 per cent. of the quadriplegics were married (Table III). Income levels (assuming a substantially higher income for the service connected (SC) veterans who in the United States 
receive compensation equalling other benefits and middle income levels) appear to have little effect on whether or not a person was married. In fact, a slightly higher ratio of marriage is noted for tetraplegics with limited income as compared with those receiving substantial compensation payments.

TABLE IV

Marital Status

\begin{tabular}{|l|c|c|}
\hline \multicolumn{2}{|c|}{ Paraplegia } \\
\hline & $\begin{array}{c}\text { Prior to or at } \\
\text { time of injury }\end{array}$ & $\begin{array}{c}\text { Present or } \\
\text { post-injury }\end{array}$ \\
\hline Single & 75 & 28 \\
Married & 73 & IO5 \\
Separated & - & I2 \\
Separated and remarried & - & 3 \\
Widowed & - & 3 \\
Widowed and remarried & - & I \\
\hline Tot & 152 & I52 \\
\hline
\end{tabular}

Note: Of 124 marriages, there were 15 separations ( $12 \%$ ), or I in $8 \cdot 2$ marriages.

\begin{tabular}{|l|c|c|}
\hline \multicolumn{2}{|c|}{ Tetraplegia } \\
\hline & $\begin{array}{c}\text { Prior to or at } \\
\text { time of injury }\end{array}$ & $\begin{array}{c}\text { Present or } \\
\text { post-injury }\end{array}$ \\
\hline Single & 39 & 23 \\
Married & 28 & 33 \\
Separated & - & 6 \\
Separated and remarried & - & 4 \\
Widowed & - & - \\
Widowed and remarried & - & 67 \\
\hline Tot AL & 67 & \\
\hline
\end{tabular}

Note: Of 44 marriages, there were ro separations $(23 \%)$, or I in 4.4 marriages.

Statistics for the study population did not support the prevalent assumption that the divorce rate among persons with spinal cord injuries is exceptionally high. In fact, separation rates appear to be lower than those of the general population. Of the I68 marriages (both paraplegic and quadriplegic) there was a total of 25 separations or a ratio of one in 6.7 marriages. However, eliminating the four separations which occurred prior to the injury gives a post-injury separation rate of 
only one in eight, both ratios well below the national average in the United States. When compared with the paraplegic group, however, a higher rate of failure is noted among the tetraplegics. A study of the data beyond that shown in the chart revealed that of the total, only nine per cent. of the patients (two quadriplegic and four tetraplegic) who married following their injuries later separated, and of this group three remarried. On the other hand, 20 per cent. of those married at the time of their injury were later separated. Of this group only four subsequently remarried. This would indicate a greater stability in marriages which occurred following the onset of paralysis (Table IV).

It has often been assumed that some girls married veterans with spinal cord injuries because of the financial benefits accruing to the wife of a service connected (SC) veteran. There appears to be no pattern to either substantiate or disprove this, however, the low rate of separation seems to indicate that if this were true, other accommodations were reached which sustained the marriages for many years.

Marriage patterns were effected by other factors. The patient who suffered a civilian injury was more apt to have been married prior to the injury and was generally older at the time of disability than was the person with a service incurred injury.

\section{FAMILY UNITS}

The household composition of those in the study group varied considerably with a natural relationship to the current family situation (Table V). Among both

TABLE V

Household Composition

\begin{tabular}{|l|r|r|r|}
\hline & Tetraplegia & Paraplegia & Tот AL \\
\hline Alone & 3 & I3 & I6 \\
Wife only & I4 & 56 & 70 \\
Wife and children & 23 & 52 & 75 \\
Children only & 2 & 2 & 4 \\
Parent(s) & I2 & I & 30 \\
Sibling & 2 & 3 & 5 \\
Sibling and family & 3 & 5 & 8 \\
Another SCI & 2 & - & 2 \\
Non-family member & 4 & I & 5 \\
Other & 2 & 2 & 4 \\
\hline Tot AL & 67 & I52 & 219 \\
\hline
\end{tabular}

the paraplegics and tetraplegics the largest number were living with a wife alone or with a wife and children. The next largest number in both groups were living with parents, but some variations of the living patterns are noted when percentages of the group totals are considered. A limited number received additional assistance, usually on a part time basis, from visiting nurses (7), attendants (13), or housekeepers 
(9) and two men were patients in nursing homes prior to admission to the veterans hospital (Table VI).

It is important to note that the integrity of the family unit had been maintained: except for three cases all pre-teen and teenage children were living in a home provided by their disabled father. The exceptions involved children living with the mother following a marriage separation.

In most cases children had been born or conceived prior to the injury, but at least one quadriplegic and nine paraplegics had fathered children following their injury.

Not only had family units been maintained in the patients concerned but in several instances, when marriage had occurred following injury, families had been established through adoption procedures. Children were usually adopted as babies or at a very early age and most couples had adopted more than one child. Two

\author{
TABLE VI \\ Family Units \\ Paraplegics with children \\ 78 had children of all ages \\ Pre-teen-32 \\ Teenage-3I \\ Adult - 34 \\ I4 had adopted children \\ Tetraplegics with children \\ 30 had children of all ages \\ Pre-teen-I4 \\ Teenage-I 4 \\ Adult - IO \\ 6 had adopted children
}

couples, one paraplegic and one tetraplegic had three adopted children. Except for two cases adoptions were by service connected veterans who would have had no problem of sufficient income for the child's support.

In most cases adult off-spring were no longer at home, although a very limited number were providing a home for the disabled father.

\title{
LIVING ARRANGEMENTS
}

The vast majority of the men chose to live in residential or country areas and not in the city. The relatively large number of men who indicated a rural environment settled principally in Maine, Vermont and New Hampshire, although some were from country areas of New York and other New England States.

Living accommodations ranged from specially built houses to apartments and mobile homes; four men reporting that trailers had proved readily adaptable for wheelchair living. Generally, houses had been newly built, remodelled or purchased with the disability in mind so that alterations were minimal. I am led to infer that major construction modifications are, in fact, seldom necessary and that a home designed for wheelchair living need not differ in appearance from other homes. The houses were often constructed with ground-level entrances or landscaped 
pathways providing gradual approaches to the entrance so requiring no ramp. For older homes the most frequent alteration was the addition of a ramp to permit independent or at least easier access to an existing entrance. Other frequently mentioned changes were wider doors and enlarged bathrooms and showers to accommodate wheelchairs or shower-chairs. For the so-called wheelchair home for which service connected veterans receive a partial government grant these modifications are required.

Only eight paraplegics and five tetraplegics reported their living accommodations to be unsuited for wheelchair living and imposed a curtailment of activities. Most indicated as the main problem inability to construct ramped or other accessible entrances.

A number of the patients reported owning a second home, a hunting camp or cottage at a lake or shore-front location. A significant number wintered in warmer climates, where they owned a second home, or rented a house or apartment. A few used travel-trailers for this purpose.

\section{FAMILY ACTIVITIES}

During my interviews I was continually impressed with the extent of family participation in social and recreational activities. The occurrence of picnics and cookouts, boating, fishing and travelling were mentioned frequently and, a number of men had enjoyed family camping trips, usually by trailer but in some cases by tent.

The spinal cord injured (SCI) father participates in as many of his children's activities such as sports coaches, teaching at Sunday School, etc. as any other parents do.

The men have experienced the joys and frustrations of seeing their children grow and often spoke proudly of their childrens' accomplishments in sports, education and vocations. They have given their daughters in marriage and recently are starting to speak of their grandchildren.

\section{CONCLUSION}

The experience of these men, living outside of a hospital for many years, proves that given proper medical care and comprehensive rehabilitation persons with spinal cord injuries can successfully participate in marital and family activities. This knowledge should provide hope and encouragement to persons more recently injured and to the physicians, nurses and rehabilitation specialists who counsel these men regarding their future as a para or quadriplegic. 